\title{
3D Printing for fashion: new paradigms of design and consumption
}

Juliana Neves Gomes

Master, Universidade de São Paulo / gomes.juliananeves@gmail.com / lattes

Suzana Helena de Avelar Gomes

PhD, Universidade de São Paulo / suzanavelarbr@gmail.com

Orcid: 0000-0002-0831-9652/ lattes

Sirlene Maria da Costa

PhD, Universidade de São Paulo / sirlene@usp.br

Orcid: 0000-0003-0522-061 1/ lattes

Silgia Aparecida da Costa

PhD, Universidade de São Paulo / silgia@usp.br

Orcid: 0000-0001-8331-538X / lattes

Sent: 02/09/2019 // Accept: 28/10/2019 


\title{
3D printing for fashion: new paradigms of design and consumption
}

\begin{abstract}
This work aimed to take an approach on 3D printing technology in the fashion system, and the importance of postponement strategies, which are leading to greater information sharing in the production chain of this sector. It is also mentionate a way to introduce mass customization based on digital networks and other emerging technologies that has been breaking the traditional B2C (business to consumer) paradigm. This study features three entry-level machinery design projects, non-industrial 3D printers, and issues related to new ways of consumption. It can be concluded that 3D printing manufacturing is associated with lean production with few material surpluses or scraps, but when it comes to buying and shipping the product these issues still seem not to be considered.
\end{abstract}

Keywords: 3D printing. Fashion. Consumption. 


\title{
Impressão 3D para vestuário: novos paradigmas de design e consumo
}

\begin{abstract}
RESUMO
Esse trabalho teve como objetivo realizar uma abordagem sobre a tecnologia de impressão $3 D$ na moda, e a importância das postponement strategies, que estão levando ao maior compartilhamento de informações na cadeia de produção desse setor. Também é mencionado nesse trabalho a manufatura social, que é uma forma de introduzir a customização em massa, baseada nas redes digitais e em outras tecnologias emergentes, e que vem quebrando 0 tradicional paradigma B2C (business to consumer). Foram apresentados nesse estudo três projetos de moda impressa em maquinário entry-level, impressoras 3D não industriais, e questões relacionadas as novas maneiras de consumo. Pode-se concluir que manufatura por impressão $3 D$ é associada a uma produção enxuta, com poucos excedentes ou retalhos de materiais, mas quando se trata da compra e envio do produto estas questões parecem ainda não serem consideradas.
\end{abstract}

Palavras-chave: Impressão 3D. Moda. Consumo. 


\title{
Impresión 3D para indumentaria: nuevos paradigmas de diseño y consumo
}

\begin{abstract}
RESUMEN
Este trabajo tuvo como objetivo adoptar un enfoque sobre la tecnología de impresión 3D en la moda, y la importancia de las estrategias de aplazamiento, que están conduciendo a un mayor intercambio de información en la cadena de producción de este sector. La fabricación social también se menciona en este trabajo, que es una forma de introducir la personalización masiva, basada en redes digitales $y$ otras tecnologías emergentes, y que ha estado rompiendo el paradigma tradicional B2C (empresa a consumidor). En este estudio, se presentaron tres proyectos de moda impresos en maquinaria de nivel básico, impresoras 3D no industriales y cuestiones relacionadas con nuevas formas de consumo. Se puede concluir que la fabricación mediante impresión 3D está asociada con la producción ajustada, con pocos excedentes o restos de materiales, pero cuando se trata de la compra y el envío del producto, estos problemas parecen no considerarse todavía.
\end{abstract}

Palabras clave: Impresión 3D. Moda. Consumo. 


\section{INTRODUCTION}

The textile market segment is not currently portrayed only by traditional industries, such as the manufacture of fibre, yarns, weaving, knitting, nonwovens and fabric finishing units. With technological and research advances, a wide field of activities emerged focused on the development and improvement of fibres, yarns, fabrics and composites (SOUZA, PACHECO, 2016).

To maintain existing markets and conquer new ones, companies have assigned characteristics to products to reshape values, such as: concepts, local and regional cultural themes as inspiration for collections, personalized pieces and, at times, have specified products as being ergonomic (GONÇALVES, LOPES, 2007).

In addition, the growing importance of postponement strategies, which consists in late customization of the product until the last possible moment to respond to realtime changes in the market, are leading to greater sharing of information in the production chain, from the first suppliers to the point of sale (AZMEH, NADVI, 2014).

Some authors have identified a new manufacture mode, called social manufacturing which allows anyone to participate in the entire manufacturing process. With this consumer involvement, long tail effects are eliminated, reducing manufacturing costs for customized products and increasing consumer satisfaction and offering high quality services. Social manufacturing is a way to introduce mass customization, based on digital networks, and other emerging technologies (BRUNO, 2016), such as 3D printing.

The use of 3D printing has been on expansion every day in online crowdsourcing communities, in which models are created and shared by users. Along with these communities 
in which the models are created, there are already printing services, in which the file is sent and the product is received at home. Some companies such as: Bathsheba Sculpture LLC, Freedom of Creation, Make Eyewear, MGX by Materialize, Rapid Made and WB Engineering already offer this service (BRUNO, 2016).

\section{3D PRINTING}

As of 2013, there was an increase in the production of clothing, footwear and accessories making use of 3D printers (KUHN, MINUZZI, 2015a). According to Kuhn and Minuzzi (2015a), 3D printing technology was patented in 1986 and not until 2010 there was a decrease in the cost of machinery in the market, reaching values below one thousand dollars.

The working principle of 3D printing, with its various techniques, is based on executing several slices of the object, obtaining each layer in a process of deposed materials on the top of a solidified previous layer (TAKAGAKI, 2012).

The Fused Deposition Modeling (FDM) is one of the 3D printing techniques, in which the material melts inside a heated print head forming a thin flexible cord as it passes through an extruder nozzle. The first layer of this melted material is deposited on a semi-sticky platform. Then, the print head is brought up to the second layer and the material is deposited successively until the object is formed, as shown in Figure 1. The quality of resolution of this process depends on the thickness of the layer, which, in this technique, is usually around $0.1 \mathrm{~mm}$. In this type of printing, thermoplastics such as ABS (acrylonitrile butadiene styrene) and PLA (poly lactic acid) are broadly used (TAKAGAKI, 2012). 
According to Wohlers (2012), the ASTM (American Society for Testing and Materials) approved the terms for a definition of manufacturing processes by adding material:

- Material extrusion - an additive manufacturing process in which material is selectively dispensed through a nozzle or orifice.

- $\quad$ Material jetting - an additive manufacturing process in which droplets of build material are selectively deposited.

- $\quad$ Binder jetting - an additive manufacturing process in which a liquid bonding agent is selectively deposited to join powder materials.

- Sheet lamination - an additive manufacturing process in which sheets of material are bonded to form an object.

- Vat photopolymerization - an additive manufacturing process in which liquid photopolymer in a vat is selectively cured by light-activated polymerization.

- Powder bed fusion - an additive manufacturing process in which thermal energy selectively fuses regions of a power bed.

- Directed energy deposition - an additive manufacturing process in which focused thermal energy is used to fuse materials by melting as the material is being deposited. 
Figure 1. 3D printing model using the FDM method

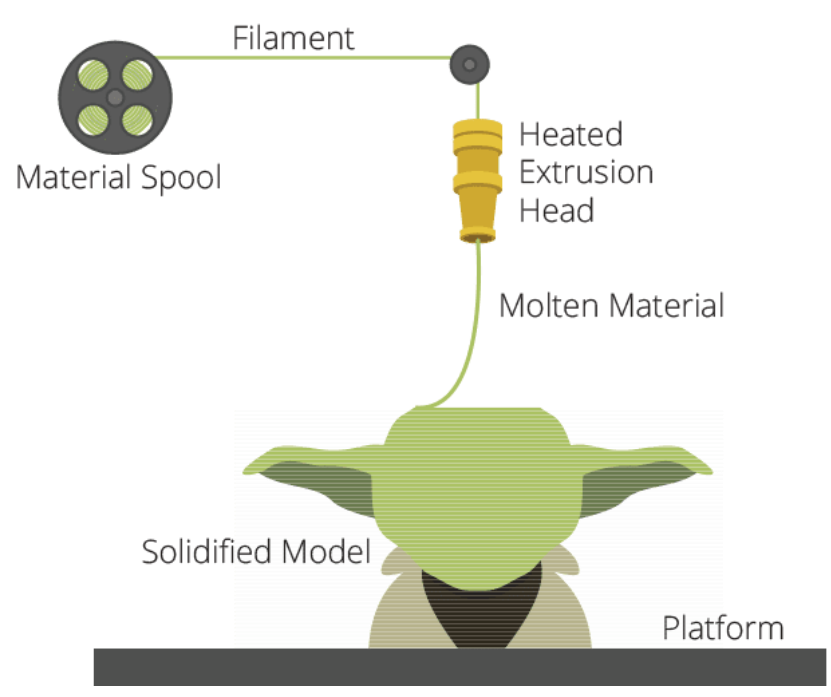

Source: 3D Printing Industry (2019).

\section{FASHION INNOVATION THROUGH 3D PRINTING}

Traditionally, innovation in the business world meant seek new technological solutions. It was from the 90's with the spread of Total Quality Management, a management philosophy that aims at the continuous improvement of the quality of products and processes, that gave birth to a new path for innovation and with that the exploration of new markets (VIANNA et al., 2012).

According to Vianna et al. (2012), it is the way the designer perceives things and acts on them that has been opening new paths to business innovation. The author and collaborators also mention that the main task of the designer is to identify problems and generate solutions, and to generate these solutions it is necessary to address the difficulties from different perspectives and angles, prioritizing collective and multidisciplinary work. This way of working is multiphasic and non-linear, it is called Fuzzy Front End, it allows interactions and continued learning. 
Furthermore, governmental works, consultancies and academic studies, national (Brazilian) and international, mention that the world society is entering its Fourth Industrial Revolution, in which the fusion of technology with each moment of our lives becomes the norm. To deal with the uncertainties of a transition of this order, fine adjustments should be repeatedly promoted to guarantee and eventually adjust - the course outlined by the strategic routes designed for the apparel industry (BRUNO, 2016).

According to Avelar (2009), creative process is also transformed and can be carried out by experimentation in different spaces, such as the laboratory, getting closer and closer to scientific research. For the author, the idea of new technologies will be fundamental for innovation in fashion. Not only in machinery and new textile creations, but also in the interaction of the body with innovative technologies, since that for the author, fashion is creation in the space of the body. To meet these needs, consumer-centric businesses are looking for innovation strategies that satisfies the growing demands with diverse interactive relationship characteristics such as consumer-to-consumer (C2C) and consumer-to-business (C2B) in addition to the traditional business-to-consumer (B2C).

Consumers are constantly looking for convenience, variety, excellent service, information and pleasant experiences. Access to global information 24/7/356 (24 hours a day, 7 days a week and 365 days a year) through digital platforms transacted traditional market places to spaces where content, context and infrastructure are reshaping the concept of value (KIM, AHN, FORNEY, 2014). Access to information empowers consumers to be creators and influencers in a global community in which they can capitalize on their social structures, relationships and 
recognition in these market spaces (KIM, AHN, FORNEY, 2014).

Away from becoming a state of dichotomy, producers and consumers will gradually take a joint creative process. Relating intensely through information and communication technologies, industry and society will be increasingly integrated by new production systems (BRUNO, 2016).

The DIY (do it yourself) tradition has been strengthening with these technologies and making room for DiWO (do it with others) and grounding the Maker Culture, composed of the makers: individuals who organize themselves with the objective of mutually supporting the development of individual or collective projects. These subjects, in addition to virtual support, physically meet at events such as Maker Fairs and spaces such as FabLabs (Factory Laboratories) (SAMAGAIA, DELIZOICOV NETO, 2015).

In other words, the logic of the internet of things (IoT Internet of Things) seems to be putting itself in place, which can be observed from the point of view of Bruno Latour (2012), dealing with the Actor-Network Theory (ANT). This theory deals with IoT from the point of view of the human sciences, emphasizing temporary collective formations, which cooperate via network and data. Both the subject and software are understood as actors, generating and processing data. Our society can be understood as actors of different natures, who act as mediators, manufacturers and places of process. In this way, business innovation in fashion can count on this dynamic that arises, using machinery and new structural forms that are constantly updated.

Consultancies, government studies and specialized articles support the reindustrialization of countries in North America and Europe. The modular automation and robotization of the confection and projects of local mini 
factories attract investments from governments and large global buyers who previously would invest in abroad production to countries with low production costs (BRUNO, 2016).

According to Gibson et al. apud Bruno (2016) the points previously mentioned as the approximation of the producer and the consumer, the reindustrialization of countries in North America and Europe and, mainly, the fusion of technology with each moment of our lives as a norm are materializing. This can be observed by analysing the daily advances of just one, among other technologies, which recently were restricted to the category of curiosities, such as the evolution of Additive Manufacturing (MA), a conceptual extension of 3D Printing or 3DP.

According to the 3D Printing Industry portal, an important information and social platform, publisher by Michael Petch, Beau Jackson and Rushabh Haria, 3D printing by extrusion of thermoplastics is the easiest, most common and best-known process of three-dimensional printing. The same website also states that the proliferation of entry-level machines (beginners) that took place in 2009 uses similar extrusion methods and generally uses the abbreviation FFF (Free Form Fabrication), once that the manufacturer Stratasys still holds the patent for the process by FDM (Fused Deposition Material).

\section{IMPRESSÃO 3D EM MAQUINÁRIO ENTRY LEVEL NA MODA}

\subsection{Danit Peleg}

Danit Peleg is currently the leading designer working with $3 D$ printing using the FDM technique. Peleg gained notoriety 
in 2015 with her graduation project, the Liberty Leading the People collection (FORGET ... 2016) and for creating a dress printed in flexible filament for the opening of the Paralympic Games in Rio de Janeiro in 2016 (PELEG, 2019).

Before that, according to Danit Peleg herself, in a lecture to TED Talks in 2016, the designer had her first contact with 3D printing in 2014, when she interned with the threeASFOUR brand in the MER KA BA collection, which had several 3D printed parts using the SLS method and nonflexible material.

Also, according to Peleg, these parts presented some problems due to being produced by rigid plastic, easily breakable. For example, the models could not sit while wearing the pieces, and, in addition, they had scratches due to the material and design (FORGET ... 2016).

In this same lecture, from 2016, Peleg points out:

\begin{abstract}
With 3D printing, designers have so much freedom to create dresses just the way they want it, but still, they are very dependent on a large and expensive industrial printer that is located far from their studios.
\end{abstract}

After Peleg observed these complications, she spent almost a year researching solutions and started using a new filament to feed the printer: Filaflex from the Spanish company Recreus. According to the manufacturer Recreus, Filaflex is a thermoplastic based on polyurethane. This new material allowed the fashion designer to print ready-made pieces, shoes, accessories and fabrics (FORGET ... 2016).

To complete her collection, Peleg took over 5000 hours to print. The designer then used 6 more entry-level FDM process printers (Figure 2). The printers used were from the European company BQ. According to the 3D Hubs portal, this printer has a reinforced chassis, suitable for stacking 
machines. With a resolution of 50 microns and measurements of $29.7 \times 21 \times 20$ centimeters, the value of this printer, which now has a new and updated generation, has average prices starting at US \$1300 (3D HUBS, 2019).

Figure 2. 3D printer used by Danit Peleg

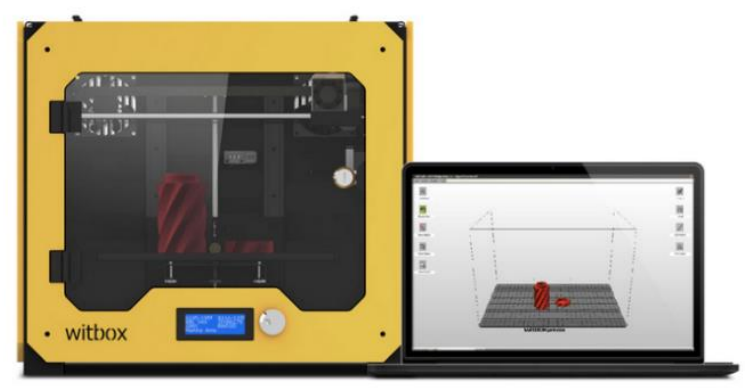

Source: Leds and chips, 2019.

According to her website, using Filaflex filament, an open source file of "fabric" for printing and having access to the team of Tech Factory Plus and XLN, Peleg completed his first Liberty Leading the People collection (Figure 3).

Figure 3. Collection Liberty Leading the People
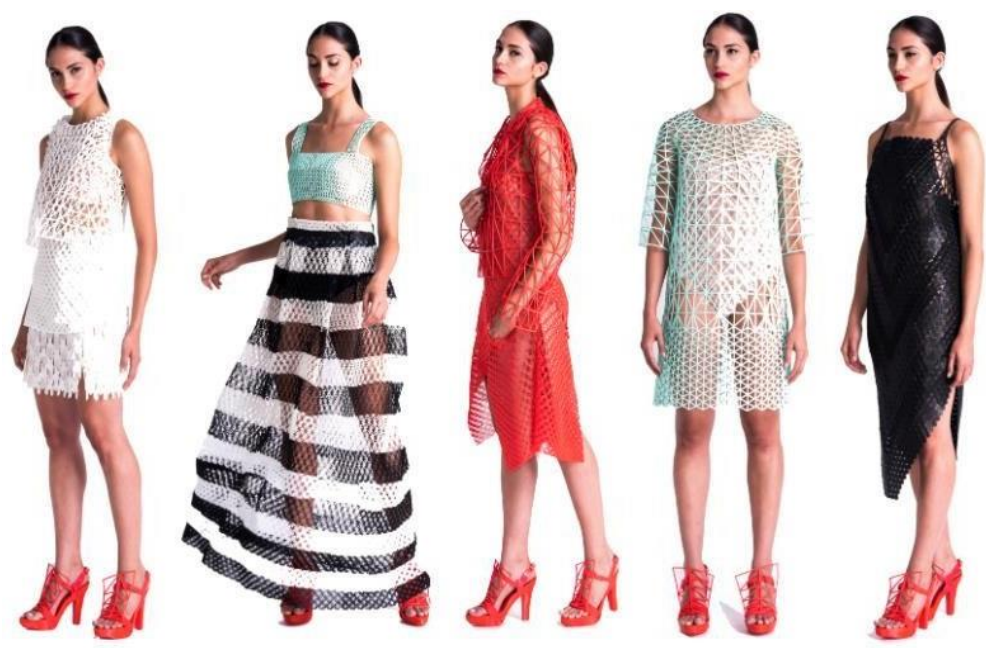

Source: Danit Peleg (2017). 
Currently, the only piece that is sold on its website is a jacket with a satin lining (Figure 4). Satin is a fabric commonly used for linings, with molds produced in the usual way and also classic stitching. In addition, the purchase is also made in a traditional way, with localized production and distribution by conventional means of transportation. Bringing the same ecological issues as the traditional apparel industry: packaging, transport, creation and localized production.

On the Peleg's website, in the purchase area of the IMAGINE Jacket, the title of the page reads Start Designing, giving the impression that the consumer will have the autonomy to create a piece for three-dimensional printing. However, the design is limited to changing colors and the selection between predefined sizes, whose only autonomous area is the choice of the word to be placed on the back. Peleg's start designing is more like a postponement strategy cited by Azmeh, Nadvi (2014) that consists of the late customization of the product until the last possible moment to respond to real-time changes in the market. Or, in this case, meet within a limited range the customer's preference in colors, pre-defined sizes and limiting them to customization with the insertion of a word with a limited number of letters. 
Figure 4. Danit Peleg wearing the jacket for sale on his website

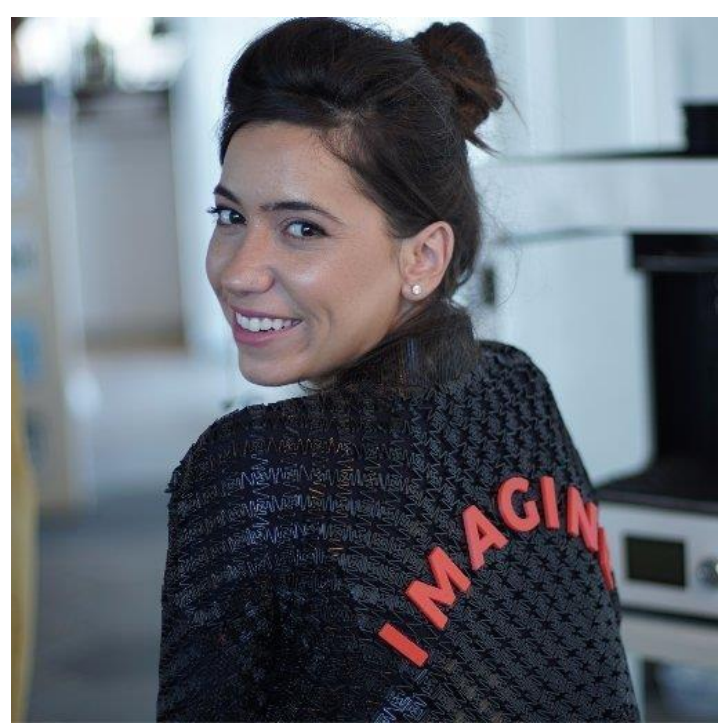

Source: Danit Peleg (2019).

\section{2. inBloom Dress}

In 2014, Australians Kae Woei Lim and Elena Lim printed the inBloom dress illustrated in Figure 5 . The dress was produced with 191 panels using the flexible PLA filament, similar to that used by Danit Peleg. The panels took 265 hours and 15 minutes to print, using only $1 \mathrm{~kg}$ of material (KUHN, MINUZZI, 2015). This piece was on display until June 2017 at the Museum of Applied Arts \& Sciences in Sydney. According to the museum's website, the dress was created in an XYZ workshop, whose founders are the Lim couple.

The creators of inBloom are committed to the open source concept and have made the files available online. In addition to the dress, the entire $X Y Z$ workshop is available for download, as well as the flexible watch, purse and wallet files. In the same profile, on the YouMagine file sharing platform, they also share a loom file. 
Figure 5. Dress inBloom

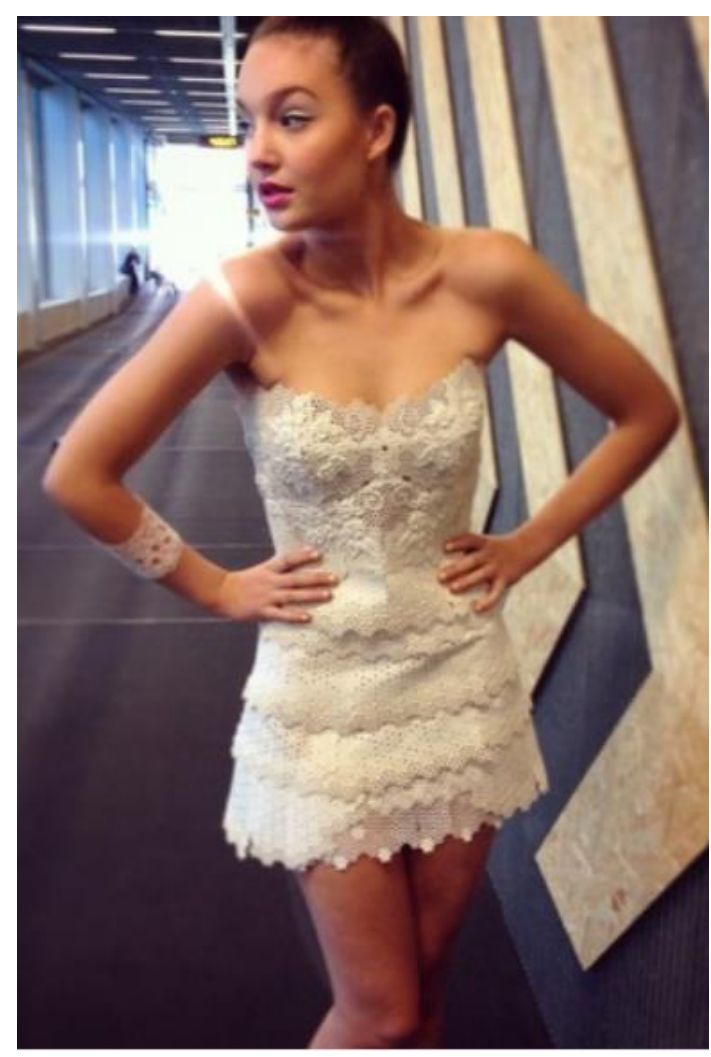

Source: XYZ Workshop (2014).

\subsection{D printing on entry level machinery in Brazil}

According to Santos and Conceição (2017), in an article for Triades magazine, additive manufacturing processes began to show signs of development in Brazil. In a partnership between the brand Plural (from Minas Gerais, south eastern Brazil, area with authorial fashion production on the rise) and the maker company 3D Lopes, "fabrics" were printed, which went on the catwalk on Minas Trend (Figure 6), a fashion event that is currently in its 25th edition.

In addition to the fashion show, the collection was on display at Minas +10 , which is part of the same event. Complementing the visitor experience, functioning 3D 
printers were included in the exhibition. The "fabrics" were printed in thermoplastic polyurethane (TPU), elastomeric filament, as used by Peleg and the Lim couple. According to Daniel Lopes, executive director of 3D Lopes, it is essential to choose a filament that allows the malleability of the pieces, according to him: "The complex geometry of the patterns is successfully achieved in 3D printing. Thus, unique products are created, to bring together high fashion and technology (MATERIALIZE, 2018).

Figure 6. Plural fashion show with 3D printed "fabrics"
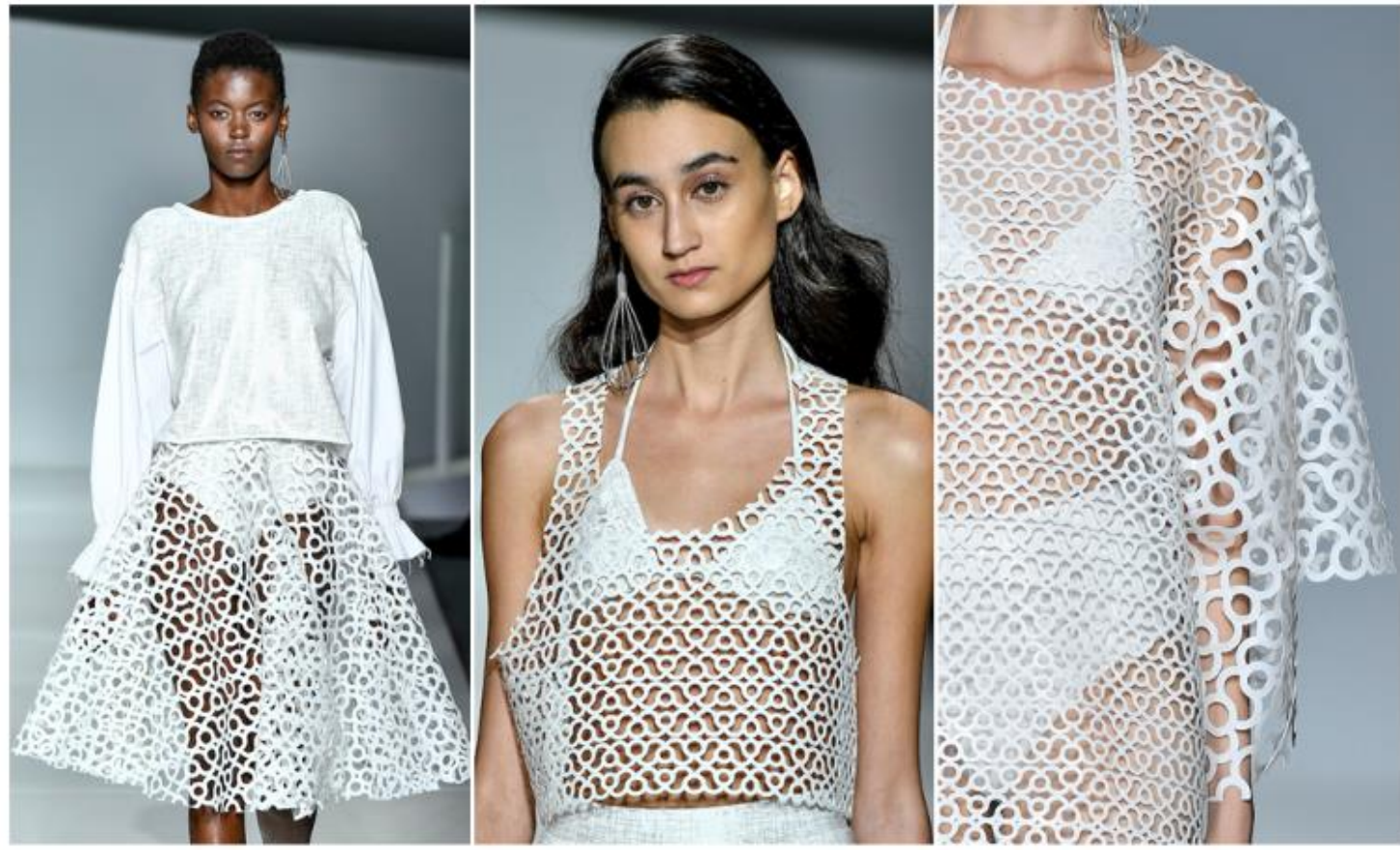

Source: Materialize (2018).

\section{CONCLUSION}

3D printing for clothing has been attracting constant public attention through media outreach. However, few designers use FDM machinery, preferring industrial 3D printers using the SLS method. 
The majority of designers do not make use of the social factor that this technology brings. Today, there are countless forums, blogs, websites, manuals and online communities about 3D printing. What impresses this growing community is the ability to produce and customize at home the products they want, and it is also the break of the B2C paradigm. As mentioned in the introduction to this paper, it is access to information that empowers consumers to be creators and influencers.

When it comes to $3 D$ printing, this technology is associated with lean production, with few surpluses or scraps of materials, but when it comes to the purchase and shipping of the product, these issues still seem not to be considered. One can notice the maintenance of the process of buying, packaging and shipping products.

\section{References}

3D HUBS. Witbox. Avaliable: https://www.3dhubs.com/3dprinters/witbox. Access: 17 ago. 2019.

3D PRINTING INDUSTRY (Org.). The Free Beginner's Guide. Avaliable: https://3dprintingindustry.com/3d-printing-basics-freebeginners-guide\#04-processes. Access: 16 fev. 2019.

AVELAR, Suzana. Moda: Globalização E Novas Tecnologias. 2. ed. Rio de Janeiro: Senac, 2011. 182 p.

AZMEH, Shamel; NADVI, Khalid. Asian firms and the restructuring of global value chains. International Business Review, [s.i.], n. 23, p. 708-717, 26 abr. 2014. Avaliable: http://dx.doi.org/10.1016/j.ibusrev.2014.03.007. Access: 21 set. 2017.

BRUNO, Flavio da Silveira. A quarta revolução industrial do setor têxtil e de confecção: a visão de futuro para 2030. São Paulo: Estação das Letras e Cores, 2016. 151 p.

CONCEIÇÃO, Maria Eloisa de Jesus; SANTOS, Jorge Roberto Lopes dos. Remodelando o Design do Vestuário com tecnologias digitais de produção. Triades: Transversalidades | Design | Linguagens, Rio de Janeiro, v. 6, n. 1, p.1-16, 10 maio 2017. Avaliable: https://triades.emnuvens.com.br/triades/article/view/95. Access: 17 dez. 2017.

PELEG, Danit (Comp.). About Us. 2019. Avaliable: https://danitpeleg.com/about/. Access: 20 jul. 2019. 
FORGET Shopping. Soon You'll Download Your New Clothes | Danit Peleg | TED Talks. Nova Iorque: Ted, 2016. Son., color. Avaliable: https://www.youtube.com/watch?time_continue $=1 \& v=$ w10Ke8OaP bk. Access: 2 ago. 2019

GONÇALVES, Eliana; LOPES, Luciana Dornbusch. Ergonomia no Vestuário: Conceito de conforto como valor agregado ao produto de moda. Actas de Diseño: II Encuentro Latinoamericano de Diseño "Diseño en Palermo". Comunicaciones Académicas, Buenos Aires, v. 1, n. 2, p.145-148, ago. 2007. Anual. Avaliable: http://fido.palermo.edu/servicios_dyc/publicacionesdc/vista/detall e_publicacion.php?id_libro=11. Access: 21 nov. 2017.

KIM, Haejung; AHN, Soo-kyoung; A FORNEY, Judith. Shifting paradigms for fashion: from total to global to smart consumer experience. Fashion And Textiles, [s.I.], v. 1, n. 1, p.1-16, 24 out. 2014. Springer Nature. http://dx.doi.org/10.1186/s40691014-0015-4.

KUHN, R.; MINUZZI, R.F. Panorama da impressão 3D no design de moda. Moda Documenta: Museu, Memória e Design, 2015a.

KUHN, Renato; MINUZZI, Reinilda de Fátima B. Novo Hamburgo. Uma introdução à impressão $3 d$ no design de moda: as primeiras peças e a chegada às passarelas. Novo Hamburgo: Enpmoda, 2015b. p. 1-6. Avaliable: http://tiny.cc/sny3ez. Access: 20 ago. 2019.

LATOUR, B. Reagregando o social. Salvador: EDUFBA, 2012.

LED and CHIPS. Witbox. Avaliable: https://ledsandchips.com/witbox. Access: 15 ago. 2019.

MATERIALIZE. Impressão 3D na moda: a experiência da 3D Lopes. 2018. Avaliable: https://materialize.3dlopes.com/impressao-3dna-moda-a-experiencia-da-3d-lopes/. Access: 12 ago. 2019.

PELEG, Danit. Liberty Leading the People. Avaliable: https://danitpeleg.com/liberty-leading-the-people-2/. Access: 20 ago. 2017.

SAMAGAIA, Rafaela; DELIZOICOV NETO, Demétrio. Educação Científica Informal na Cultura Maker. $X$ Encontro Nacional de Pesquisa em Educação em Ciências - X Enpec, Águas de Lindóia, nov. 2015.

SOUZA, Flávio Avanci de; PACHECO, Noémia Maria Ribeiro de Almeida Carneiro. Funcionalização de Materiais Têxteis. Icônica, Apucarana, v. 1, n. 2, p.177-201. jan. 2016. Avaliable: http://revistas.utfpr.edu.br/ap/index.php/iconica/article/view/54. Access: 21 nov. 2017.

TAKAGAKI, Luiz Koiti. TECNOLOGIA DE IMPRESSÃO 3D . Revista Inovação Tecnológica, São Paulo, v. 2, n. 2, p. 28-40, 20 out. 2012. Avaliable: http://rit.faculdadeflamingo.com.br/ojs/index.php/rit/article/view/ 54/71. Access: 25 ago. 2016

VIANNA, Maurício et al. Design Thinking: Inovação em negócios. Rio de Janeiro: Mjv Press, 2012. 161 p. 
WOHLERS, T. Recent trends in additive manufacturing. 17th European Forum on Rapid Prototyping and Manufacturing, Paris, 12-14 junho 2012.

XYZ WORKSHOP. InBloom Dress by XYZ Workshop. 2014. Avaliable: https://www.youmagine.com/designs/inbloom-dressby-xyz-workshop. Access: 2 jul. 2019. 